DOI https://doi.org/10.30525/978-9934-26-148-0-12

\title{
ДОСВІД УКРАЇНИ У ЗАХИСТІ ЛЮДСЬКИХ ПРАВ В ЄВРОПЕЙСЬКОМУ СУДІ $З$ ПРАВ ЛЮДИНИ
}

\author{
Цебенко С. Б. \\ кандидат юридичних наук, доцент кафедри теорї та філософії права, \\ конституиійного та міжнародного права \\ Навчально-наукового \\ Інституту права, психології та інноваційної освіти \\ Національного університету «Львівська політехніка» \\ м. Львів, Україна
}

Права людини впродовж всієї історії людства були однією з найважливіших та найактуальніших проблем. Сучасний етап державотворення відзначається значною увагою до забезпечення основних прав та свобод людини на національному та міжнародному рівнях.

Україна ратифікувала Конвенцію про захист прав людини та основоположних свобод 1950 р. (далі - Конвенція, ЄКПЛ) 17 липня 1997 року, а ратифікаційні грамоти в Раду Свропи передала 11 вересня 1997 року. 3 цього часу Конвенція є джерелом права в Україні i визнається юрисдикція Європейського суду з прав людини (ЄСПЛ, Страсбурзький суд) в усіх питаннях, що стосуються тлумачення i застосування Конвенції.

В Україні джерелом права $є$ не лише Конвенція, а 3 прийняттям Закону України «Про виконання рішень та застосування практики Європейського суду з прав людини» від 23 лютого 2006 р. № 3477-IV (далі - Закон) джерелом права є також практика ССПЛ, що включає в себе всю без винятку практику Свропейського суду з прав людини та Європейської комісії з прав людини (ст. 1 та ст. 17 Закону) [1].

Протягом багатьох років імплементація норм Конвенції та застосування практики ЄСПЛ при здійсненні правосуддя в Україні запроваджувались досить повільно. Це зумовило масові порушення прав людини і стало причиною численних звернень до ЄСПЛ проти України. $[2$, c. 64]. Тому вищезазначений Закон України якраз і був прийнятий 3 метою усунення причин порушення Україною СКПЛ і протоколів до неї та зі створенням передумов для зменшення числа заяв до ССПЛ проти України. [1].

Тривалий час Україна займає лідируючі позиції по кількості скарг поданих до ЄСПЛ проти України. 
Станом на 31.12.2019 загальна кількість справ на розгляді Страсбурзького суду становила 59800 справ проти держав - сторін Конвенції, з них 8850 справ - проти України, що складає 14,8 \% від загальної кількості справ [3].

Станом на 31.12.2020 на розгляді в Свропейському суді перебувало загалом 62000 справ проти держав - сторін Конвенції, з них 10400 справ - проти України, що складає 16,8 \% від загальної кількості справ та $\epsilon$ третьою серед держав-учасниць [4].

В Україні велика кількість надісланих до ЄСПЛ скарг стосуються таких питань як неналежні умови тримання під вартою, надмірна тривалість тримання під вартою, а також надмірну тривалість провадження у цивільних та кримінальних справах, де вони $\epsilon$ сторонами [4].

Велика кількість звернень до ЄСПЛ свідчить про наявність недоліків у національній системі правосуддя та про недосконалість механізму захисту прав та свобод людини і громадянина в державі.

Стосовно кількості рішень прийнятих проти України за період існування ССПЛ, то можна сказати, що станом на кінець 2019 року проти України ССПЛ виніс 1413 рішень, з яких у 1383 визнав порушення Україною положень Конвенції [5]. 109 рішень проти України було винесено ЄСПЛ у 2019 році [3]. У 2020 році Страсбурзьким судом було прийнято ще 86 рішень проти України [6].

Велика кількість заяв до ЄСПЛ в Україні зумовлена також i російсько-українським конфліктом, який триває ще з 2014 року. Станом на 01.01.2021 7898 справ стосуються порушення прав заявників в Автономній Республіці Крим та на тимчасово окупованій території Луганської та Донецької областей: - 6879 справ стосуються подій на сході України, з яких 6033 заяви подані проти України, 48 - проти Російської Федерації, 791 - проти обох держав. 1019 справ стосуються подій в Криму [4].

21 січня 2021 року ССПЛ прийняв п'ять рішень, а саме «Shmorgunov and others v. Ukraine» (№ 15367/14 та 13 інших), «Vorontsov and others v. Ukraine» (№ 58925/14 та 4 інших), «Lutsenko and Verbytskyy v. Ukraine» (№ 12482/14 та № 39800/14), «Kadura and Smaliy v. Ukraine» (№ 42753/14 та № 43860/14), «Dubovtsev and others v. Ukraine» (№ 21429/14 та 9 інших). ССПЛ у цих справах констатував низку порушень прав i свобод людини під час подій, які пов'язані з протестними акціями Майдану в м. Києві та інших містах України наприкінці 2013 та на початку 2014 рр. Порушення стосувались, зокрема, випадки силових розгонів протестувальників, їх затримання, викрадення активістів та неналежного поводження 3 ними, та відповідних проваджень. 
ЄСПЛ зазначив, що щодо всіх заявників були вчинені певні дії правоохоронцями або «тітушками» - недержавними агентами під контролем правоохоронців. Суд встановив, зокрема, що владні органи умисно застосовували жорстоке поводження та що держава була відповідальна за вбивство одного з протестувальників. Також ЄСПЛ установив, що офіційні розслідування стосовно цих подій у багатьох випадках були неефективними [7, с. 7].

Однак, винесення рішення в конкретній справі не закінчує судовий розгляд. Адже, це рішення містить заходи індивідуального характеру, а також часто і заходи загального характеру. Це означає, що метою таких рішень $є$ приведення національного законодавства держави у відповідність до європейських стандартів, а саме до норм ЄКПЛ [8, с. 7]. Адже, як було вже сказано, практику ССПЛ можна вважати офіційною формою інтерпретації основних (невідчужуваних) прав кожної людини, закріплених і гарантованих Конвенцією.

Обов'язок поважати рішення ЄСПЛ покладається також і на національні суди. Йдеться не лише про врахування позиції Страсбурзького суду при тлумаченні положень Конвенції та перекладі положень внутрішнього законодавства відповідно до цього тлумачення, а й про вжиття конкретних дій, спрямованих на виконання рішення ЄСПЛ [9, с. 59].

Отже, узагальнивши вищенаведене, можна підсумувати, що практика ЄСПЛ відіграє важливу роль у процесі реформування правосуддя, оскільки сприяє наближенню національної правової системи до європейських стандартів 3 прав людини. Чинне законодавство не може повноцінно забезпечувати захист особи чи встановити справедливість, якщо воно належно не виконується. На основі вже існуючих на сьогодні рішень ЄСПЛ судді можуть правильно зрозуміти норму закону та доцільно ії застосовувати, що слугуватиме покращенню забезпечення прав людини, правильному розумінню та виконанню Конвенції в Україні.

\section{Література:}

1. Про виконання рішень та застосування практики Європейського суду з прав людини: Закон України від 23 лютого 2006. № 3477-IV. База даних «Законодавство України» / BP України. URL: https://zakon.rada.gov.ua/laws/show/3477-15 (дата звернення: 17.09.2021).

2. Толкачова I. А., Пущик I. М. Особливості застосування практики Європейського суду з прав людини при здійсненні правосуддя в Україні. Юридичний вісник. 2018. № 3. С. 64 - 68. 
3. Щорічний звіт про результати діяльності Уповноваженого у справах Європейського суду з прав людини у 2019 році № 3303/5.2.2/4-20 від 02.04.2020 p. Міністерство юстиції України: офиц. веб-сайт. URL: https://minjust.gov.ua/files/general/2020/04/02/20200402115102-80.pdf (дата звернення: 17.09.2021).

4. Щорічний звіт про результати діяльності Уповноваженого у справах Європейського суду з прав людини у 2020 році № 2700/5.2.2/421 від 31.03.2021 р. Міністерство юстиції України: офиц. веб-сайт. URL: https://minjust.gov.ua/files/general/2021/04/02/20210402145846-32.pdf (дата звернення: 17.09.2021).

5. Violations by Article and by State 1959-2019. URL: https://www.echr.coe.int/ Documents/Stats_violation_1959_2019_ ENG.pdf (accessed: 18.09.2021).

6. Violations by Article and by State 2020. URL: https://www.echr.coe.int/Documents/Stats_violation_2020_ENG.pdf (accessed: 18.09.2021).

7. Огляд рішень Європейського суду з прав людини (січень 2021 року). Рішення за період із 11.01.2021 по 29.01.2021 / Відпов. за вип.: О. Ю. Тарасенко, Д. П. Мордас, Р. Ш. Бабанли. Київ, 2021. 71 стор. URL: https://supreme.court.gov.ua/userfiles/media/new_folder_for_uploads/supre me/Oglyad_ESPL_01_2021.pdf?fbclid=IwAR2TI5TPNpzWCUgwJcknbt0E RZeZzlshHecRF7y2Ng9xdCcS44hjnF02GhQ (дата звернення 15.09.2021).

8. WYROK W STRASBURGU TO NIE KONIEC! Raport na temat wykonywania wyroków Europejskiego Trybunału Praw Człowieka Wydanie trzecie uzupełnione. Warszawa, listopad $2020 \mathrm{r}$. URL: https://www.senat.gov.pl/gfx/senat/userfiles/_ public/k10/komisje/2020/kpcpp/m/wykonywanie-wyrokow-etpc-2020-finweb.pdf_(accessed: 16.09.2021).

9. Górski Michał. Prawo do poszanowania życia rodzinnego cudzoziemców w polskim porządku prawnym na tle orzecznictwa Europejskiego Trybunału Praw Człowieka. Rozprawa doktorska napisana pod kierunkiem dr. hab. Michała Kowalskiego. Kraków 2018. 329 p. 31454/10 URL: https://www.researchgate.net/publication/340082550_Prawo_do_poszanowania_zycia_rodzinnego_cudzoziemcow_w_polskim_porzadku_prawn ym_na_tle_orzecznictwa_Europejskiego_Trybunalu_Praw_Czlowieka (accessed: 16.09.2021). 